Journal of British Studies 60 (July 2021): 632-657. doi:10.1017/jbr.2021.61

(C) The North American Conference on British Studies, 2021. This is an Open Access article, distributed under the terms of the Creative Commons Attribution licence (http://creativecommons.org/licenses/by/4.0/), which permits unrestricted re-use, distribution, and reproduction in any medium, provided the original work is properly cited.

\title{
"Nobody's Children"? Political Responses to the Homecoming of First World War Veterans in Northern and Southern Ireland, 1918-1929
}

Emmanuel Destenay

\begin{abstract}
At the time when Irish veterans of the Great War were being demobilized, Ireland was in a period of profound social, political, and cultural change that was irreversibly transforming the island. Armistice and the veterans' relief at having survived the conflict and being back with family could not eclipse the overwhelming political climate they met on their homecoming. This article draws on the 1929 Report by the Committee on Claims of British Ex-servicemen, commissioned by the Irish Free State to investigate whether Irish veterans were discriminated against by the Southern Irish and British authorities. The research also makes use of a range of underexploited primary sources: the Liaison and Evacuation Papers in the Military Archives in Dublin, the collection of minutes of the Irish Sailors' and Soldiers' Land Trust in the National Archives in London, and original material from the Public Record Office of Northern Ireland and the National Archives of Ireland relating to economic programs for veterans. A comparative approach of to the respective demobilizations of veterans in Northern and Southern Ireland in the 1920s reveals that disparities in formal recognition of their sacrifice and in special provision for housing and employment significantly and painfully complicated their repatriation.
\end{abstract}

And when the time came to rejoice over the war's ending, was there anything more tragic than the position of men who had gone out by the thousands for the sake of Ireland to confront the greatest military power ever known in history, who had fought the war and won the war, and who now looked at each other with doubtful eyes? -Stephen Gwynn, "Irish Regiments"1

hen Irish veterans were demobilized after World War I, they returned to an Ireland in turmoil, in the midst of profound social, political, and cultural changes that would transform the island. In less than a decade,

Emmanuel Destenay is a research fellow in the history department of Sorbonne University and a fellow of the British Higher Education Academy. This article draws on the research done for his book published by the University College Dublin Press, Shadows from the Trenches: Veterans of the Great War and the Irish Revolution (1918-1923) (Dublin, 2021). He thanks Jeffrey Collins and Sandra den Otter, the editors of Journal of British Studies, for supporting the publication of this article, the three anonymous reviewers for their detailed comments and suggestions, and Stefan Brown, Maureen Garvie, and Ellen Wert for the time they have spent on editing the article. Please direct any correspondence to emmanuel.destenay@wanadoo.fr.

${ }^{1}$ Stephen Gwynn, "Irish Regiments," in Great Irishmen in War and Politics, ed. Felix Lavery (London, $1920), 149-86$, at 186. 
while the country struggled with repercussions of a global conflict and a national rebellion, acute, unresolved tensions between the aspirations and allegiances of Unionist and Nationalist constituencies almost led to armed conflict between paramilitary organizations. The December 1918 General Elections ushered in a new political era for the country, establishing the conditions for the convening of the first national assembly. In January 1919, the British government's refusal to recognize the legitimacy of the Irish parliament Dáil Éireann (a corollary of which was the determination of the newly elected Southern Irish MPs not to sit at Westminster) began the War of Independence. In the North, resistance to the prospect of pledging allegiance to a parliament in Dublin led six of the nine counties of Ulster to separate and form Northern Ireland under the Government of Ireland Act (1920). In December 1921, the Anglo-Irish Treaty established the Irish Free State, an autonomous entity associated with the British crown. Ratified by a majority of members of Dáil Éireann in January 1922, the treaty conjured up a political schism between pro- and anti-treaty forces that resulted in the Irish Civil War (1922-23), ending with the capitulation of the anti-treaty factions in May 1923.

Irish servicemen had fought in the First World War and helped win it, but they now looked at the political transformation of their homeland with uncertainty. The Armistice and their relief at having survived the conflict and being back with their families could not eclipse their many political doubts. No sooner had they been demobilized than many war veterans became engaged in the struggle for independence alongside the republican brigades. ${ }^{2}$ Among the 115,550 republicans allegedly belonging to the Irish Republican Army (IRA) during the War of Independence ${ }^{3}$ (an estimated fifteen thousand men actively participated in the armed conflict against the crown forces ${ }^{4}$ ) were hundreds of veterans, possibly as many as a thousand, who joined the IRA between 1919 and 1921. ${ }^{5}$ That number did not reflect most of the trajectories of more than 150,000 Irish veterans, ${ }^{6}$ as clearly "the great majority of ex-servicemen did not take part in the struggle for the independence of their

\footnotetext{
${ }^{2}$ Richard Grayson, Dublin's Great Wars: The First World War, the Easter Rising and the Irish Revolution (Cambridge, 2018), 283-99.

${ }^{3}$ John Borgonovo, “Army without Banners': The Irish Republican Army, 1920-1921," in Atlas of the Irish Revolution, ed. John Crowley, Donal Ó Drisceoil, and Mike Murphy (Cork, 2017), 390-99.

${ }^{4}$ Charles Townshend, The British Campaign in Ireland, 1919-1921 (Oxford, 1975), 179.

5 Tracking veterans of the Great War enrolled in the IRA remains a challenging and almost impossible task. Weekly and monthly reports from the Royal Irish Constabulary inspectors sometimes underline a unit training under the supervision of former servicemen. However, they do not offer exact numbers of British veterans fighting with the republicans. These reports refer only to "large numbers of ex-servicemen," "some ex-servicemen," or "a number of ex-servicemen" fighting in the IRA. Witness statements from former IRA members give more precision when it comes to individuals. After consulting the weekly and monthly police reports between January 1919 and July 1921 in The National Archives in London and searching the Bureau of Military History (Military Archives of Ireland), I have identified seventyeight witness statements and police reports allowing me to estimate at least 240 veterans. Several files mentioned a "large number of veterans" fighting with the IRA. Without being able to state with certainty what "large number" meant (most likely at least fifty), I therefore suggest that possibly up to one thousand veterans of the Great War took part in the struggle against the British Forces. For more information on the participation of First World War veterans in the Irish War of Independence, see Emmanuel Destenay, "Allégeances et transferts de loyauté: La contribution des anciens combattants irlandais de la Première Guerre mondiale à la guerre d'indépendance (1919-1921)," 20 \& 21 Revue d'Histoire 142, no. 2 (2019): 61-74.

${ }^{6}$ Report by the Committee on Claims of British Ex-servicemen (Dublin, 1929), 3.
} 
country."7 Therefore, I do not focus on the active veteran minority who rejected British rule in Ireland and helped transform the IRA into a paramilitary organization. Instead, I focus on the return to civilian life of veterans of the First World War.

Historical accounts have been swift to portray the Irish veterans of the First World War as a community that suffered persecution and discrimination. In the late 1990s, historians Jane Leonard and Peter Hart argued that the Irish Republican Army purposely persecuted veterans during the War of Independence. ${ }^{8}$ Claims were made that in Southern Ireland after partition, the Irish Free State sought to erase any public memory of the imperial war dead, ${ }^{9}$ while the authorities in Northern Ireland honored and praised their sacrifice. ${ }^{10}$ This disparity fed the feeling among Southern veterans that they were not welcomed back. Recent studies have questioned these conclusions as inadequately considering the reasons why these veterans were targeted by the IRA; ${ }^{11}$ they explore veterans' homecoming in Southern Ireland in relation to the established Irish Free State. ${ }^{12}$ Paul Taylor has concluded that the British government fulfilled its obligations toward the Irish war veterans; he maintains that their "war service brought no privilege from the [Irish Free] State or community but neither did it result in discrimination." 33 While Taylor sheds valuable light on veterans' homecoming, a comparative approach to their repatriation in Northern and Southern Ireland would help determine whether Northern Ireland, as still a full member of the United Kingdom, did more to reintegrate veterans socioeconomically than the autonomous Irish Free State. Furthermore, a comparative approach would indicate whether there were significant differences in their reception by their respective societies and the attention they received from the imperial government after partition.

In this article, therefore, I explore the homecoming of veterans of the First World War in both Northern and Southern Ireland. ${ }^{14}$ Moreover, I go beyond comparing their respective reintegration and situate the question of political responses to their homecoming in relation to state building and national identities. My research reappraises the claim that political actions were aimed at erasing or putting aside the

\footnotetext{
${ }^{7}$ Henry Harris, The Irish Regiments in the First World War (Cork, 1968), 203.

${ }^{8}$ Jane Leonard, "Getting Them at Last: The I.R.A. and Ex-Servicemen," in Revolution? Ireland, 19171923, ed. David Fitzpatrick (Dublin, 1990), 118-29; Peter Hart, The I.R.A. and Its Enemies: Violence and Community in West Cork, 1916-1923 (Oxford, 1998), 311.

9 Jane Leonard, "The Twinge of Memory: Armistice Day and Remembrance Sunday in Dublin since 1919," in Unionism in Modern Ireland: New Perspectives on Politics and Culture, ed. Richard English and Graham Walker (Dublin, 1996), 99-114; Jane Leonard, "Survivors," in Our War: Ireland and the Great War, ed. John Horne (Dublin, 2008), 209-23; Jeffery Keith, Ireland and the First World War (Cambridge, 2001), 67.

${ }^{10}$ Catherine Switzer, Unionists and Great War Commemoration in the North of Ireland, 1914-1939 (Dublin, 2007), 96.

${ }^{11}$ Emmanuel Destenay, "Les anciens combattants irlandais de la Première Guerre mondiale: une communauté martyrisée?," Vingtième Siècle: Revue d'Histoire 136, no. 4 (2017): 43-56.

12 Paul Taylor, Heroes or Traitors? Experiences of Southern Irish Soldiers Returning from the Great War, 1919-1939 (Liverpool, 2015), 75-88.

13 Taylor, Heroes or Traitors?, 245.

${ }^{14}$ I use Northern and Southern Ireland throughout to refer to the two political entities as established by the Government of Ireland Act 1920. The twenty-six counties of Southern Ireland became, in January 1922, the Irish Free State, following the Anglo-Irish Treaty; the six counties of Ulster that seceded from the rest of the island became Northern Ireland. While Northern Ireland remained fully part of the United Kingdom, Southern Ireland was given some degree of autonomy.
} 
memory and sacrifice of returning veterans in Southern Ireland, while questioning the view that veterans there were discriminated against in comparison with their former comrades-in-arms in the North, as some at that time believed. Comparing the grievances of Northern and Southern Irish veterans can help determine whether those who remained in the United Kingdom after the Anglo-Irish Treaty considered themselves to be better treated and were more at ease with their adjustment to civilian life than were their former comrades in the South. I assess how the challenges faced by Southern veterans differed from those in the North, whether the Anglo-Irish Treaty (1921) complicated daily life for Southern veterans, and whether the Irish Free State and the British government bore some responsibility for the resentment that Southern Irish veterans felt.

In contrast to Taylor's conclusions, my research reveals that veterans in Southern Ireland were undeniably angered by the absence of official recognition, even as Northern Ireland enshrined its veterans' collective sacrifice within the Unionist commemorative canon. Yet while that lack of recognition remained a legitimate concern for Southern Irish veterans, both Northern and Southern veterans resented the shortage of "houses for heroes," and in both jurisdictions they faced unemployment. Both groups relied heavily on private employers and companies to provide for their living, but this support did not materialize on a wide scale, as employment in this sector was limited. Local authorities helped alleviate unemployment among Northern and Southern Irish veterans both before and after partition. However, while state authorities in Northern Ireland endeavored to pass resolutions in support of veterans independently from the imperial government, the Irish Free State rejected any moral obligation, clearly regarding "British" veterans as an imperial debt. If a feeling of injustice prevailed among Southern Irish veterans, it was due not only to the transition from an imperial to an autonomous political entity but also to the indifference of the Dáil Éireann, which reinforced feelings among them that they were "nobody's children." 15

My research draws on the Report by the Committee of Claims of British Ex-servicemen (1929). The committee was established by the Irish Free State following a motion presented by William Archer Redmond and backed by other members of Dáil Eireann to investigate whether veterans had been discriminated against by the Southern Irish and British authorities. ${ }^{16}$ To strengthen the analysis, I have consulted a range of underutilized primary sources: the minutes of the Irish Sailors' and Soldiers' Land Trust at the National Archives in London, the original material in the Public Record Office of Northern Ireland and in the National Archives of Ireland relating to the economic programs for former servicemen living in the thirty-two counties, and testimonies in the Colonial Office documents. The research brings to light the principal reasons that significantly complicated the homecoming of veterans and contributed to their despondency in the 1920s. First, following the Irish War of Independence and the Irish Civil War, Irish society underwent a political crisis that established a host of new martyrs and new heroes who were celebrated for their opposition to the British army. Southern authorities privileged this new group of veterans closely

${ }^{15}$ Michael Heffernan, Speech to Dáil Éireann, 16 November 1927, Dáil Éireann Debates (1927), vol. 21, col. 1430 .

${ }^{16}$ William Redmond, Speech to Dáil Éireann, 16 November 1927, Dáil Éireann Debates (1927), vol. 21, col. 1394; Report by the Committee on Claims of British Ex-servicemen (Dublin, 1929). 
associated with the establishment of the Free State over veterans of the First World War as a social group. Whereas Northern Irish authorities remembered, honored, and commemorated veterans and gave them a privileged place within the political ethos, the Irish Free State deliberately excluded them from the national myth as it went about the task of shaping the collective memory of Southern Ireland. Spurred by a desire to revive the nation's Gaelic past, Southern authorities built a national myth in accordance with a political and cultural agenda. Even though commemorations throughout Ireland anchored the memory of the First World War in the political landscape, veterans were differently commemorated in the twenty-six Southern counties.

In the second section of the article, I analyze the preoccupations of veterans in relation to the construction of so-called colonies ${ }^{17}$ for former British officers and men. Veterans in both Northern and Southern Ireland wrongly blamed the British authorities for the straitened conditions in which they found themselves, feeding their frustrations. In the third section, I deal with unemployment and explore how veterans reacted to the various schemes enacted in both Northern and Southern Ireland. Unemployment, exacerbated by the British government's prohibition of Irish emigration in 1914, plagued both the Northern and Southern communities. The British government adopted several employment schemes for veterans of all ranks. However, even though British and local authorities in Ireland unconditionally backed the economic reintegration of demobilized troops, the scarcity of employment resulted in an undercurrent of despair and resentment among Northern and Southern veterans. Most importantly, after the signing of the Anglo-Irish Treaty (1921), the decision of the Southern authorities to offer preferential treatment in terms of employment to former members of the National Army reinforced the belief among imperial veterans that they had been abandoned.

\section{COMPETING HEROISMS: THE MAKING OF HEROES IN NORTHERN AND SOUTHERN IRELAND}

Throughout Ireland, those who had served during First World War had expected to be honored for having fought to defeat the Central Powers. But while their contribution to the European restoration of peace was enshrined within the collective European memory, in Southern Ireland a new generation of combatants was being valorized.

Two watershed constitutional enactments - the Government of Ireland Act in 1920, dividing North and South, and the Anglo-Irish Treaty of December 1921, recognizing Southern Ireland as an autonomous free state still associated with the British crown-brought about a partition in terms of the official orchestration of popular memory. The two geographical spheres differed profoundly in their integration of veterans of the First World War in their national myths.

\footnotetext{
17 Reference to colonies for veterans in Ireland can be found in the records of the Irish Sailors' and Soldiers' Land Trust in The National Archives (hereafter citations to this repository are abbreviated as TNA): Irish Sailors' and Soldiers' Land Trust: London Headquarters: Southern Ireland, Correspondence Files, 1924-1987, TNA, AP 1; Irish Sailors' and Soldiers' Land Trust: London Headquarters: Northern Ireland, Correspondence Files, 1923-1987, TNA, AP 2.
} 
From 1918 onward, and particularly after the signing of the Government of Ireland Act and King George V's inauguration of the Northern Irish Parliament in June 1921, Northern Ireland sought to reassert its British identity and loyalty to London. The six loyal counties anchored the memory of the First World War within their Unionist canon, welcoming and acknowledging their returning soldiers as heroes and martyrs. ${ }^{18}$ Politicians, county councils, and government agencies praised their sacrifice. Northern Irish veterans played an important part in cementing political, cultural, and historical bonds with Great Britain. Commemorations of Armistice Day were substantial gatherings. Beyond the two-minute ritual silence to honor the memory of the departed, 11 November displayed the defining cultural and political features of the newly created state. Unionist banners and British anthems and songs all contributed to the explicitly British pathos at the heart of the commemorations. The 1916 Battle of the Somme, in which so many "sons of Ulster" died, became a new historical and cultural benchmark for the Unionist majority. ${ }^{19}$ In the Unionist ceremonies of 12 July 1918 and 12 July 1919, the battle came to be incorporated within the liturgy of a loyal Ulster identity. ${ }^{20}$ During the unveiling of the war memorial in Coleraine in November 1922, Northern Ireland's prime minister, Sir James Craig, asserted that the sacrifice of the 36th (Ulster) Division reinforced the need to "stand firm to give away none of Ulster's soil." 21 The commemorative liturgy associating the First World War with the celebration of British patriotism angered many Northern Irish Catholic and Nationalist veterans; ${ }^{22}$ in 1924, a group of Derry Nationalist veterans chose not to participate in the 11 November ceremonies "as they felt the political overtones of the event was antithetical to their reasons for volunteering in the first place." ${ }^{23}$ As Richard Grayson has explained, "Any Nationalist attending would be surrounded by the flags and symbols of a country to which they felt no allegiance, in a crowd singing songs that had nothing to do with nationalists' national identity." 24 Local and governmental authorities of Northern Ireland faithfully commemorated veterans' role in the First World War, yet enfolded them within a political ethos that meant that only Unionist veterans could identify with the ritual. Catholic and Nationalist veterans felt excluded from commemorations that seemed to imply that their participation in the First World War denoted unconditional loyalty to Britain. Partition magnified divisive political cultures and accentuated the Unionist liturgy of the Northern Irish State, triggering a reactionary identity in opposition to the South and unleashing an overarching unifying culture at the expense of Catholic and Nationalists groups.

In Southern Ireland, the postwar Irish Free State refrained from shaping any collective memory of the Great War. Authorities redefined the cultural benchmarks of

${ }^{18}$ Switzer, Unionists and Great War, 96.

${ }^{19}$ Heather Jones, "Church of Ireland Great War Remembrance in the South of Ireland, a Personal Reflection," in Towards Commemoration: Ireland in War and Revolution, 1912-1923, ed. John Horne and Edward Madigan (Dublin, 2013), 74-82, at 75.

${ }^{20}$ Richard Grayson, Belfast Boys: How Unionists and Nationalists Fought and Died Together in the First World War (London, 2010), 168.

21 "Coleraine Memorial unveiled by Sir J. Craig. A Tribute to the Fallen," Belfast Telegraph, 11 November 1922.

${ }^{22}$ Myers, The Great War, 1.

${ }^{23}$ Myers, 67.

${ }^{24}$ Grayson, Belfast Boys, 171. 
the Irish collective memory, generating the state's own myths and its own veterans, thus establishing a clear difference between former IRA members and war veterans. Faced with the impossibility of achieving a United Ireland, the Irish Free State had to accept that Northern Ireland would not be subject to its authority. The newly elected members of the Dáil Éireann, in close association with the Catholic Church, undertook to set in motion the Sinn Féin agenda and to revive the country's Gaelic past. To do so, they relied on ancient myths and glorified the generations of Irish men and women who had participated in the struggle for independence. ${ }^{25}$ Not only were veterans of the First World War demobilized in the middle of a conflict pitting the Irish Republican Army against the British forces but they now witnessed the redefinition of a collective identity in which they had no particular role. The Southern collective memory crystalized an Irish identity "founded on the Catholic-Gaelic cultural nationalism, which had developed in the nineteenth century in reaction to British domination and to the unionist discourse." 26 The Free State revived a "traditional vision of national identity derived from Irish cultural nationalism." 27 The newly crafted national myth anchored through the education system a Catholic and Nationalist ethos in the collective mentality of primary and secondary school pupils. ${ }^{28}$

From the end of the conflict and throughout the 1920s and 1930s, commemorations of 11 November were the focus for a strong feeling of pride throughout Ireland. On Armistice Day, 1924, tens of thousands of people gathered to watch twenty thousand veterans parade through the center of Dublin. ${ }^{29}$ Garrison towns and ports such as Tralee ${ }^{30}$ and $\mathrm{Cobh}^{31}$ observed a two-minute silence in the presence of veterans and the relatives of departed soldiers. In the Irish Free State, "one of the most famous, visible, public and participatory charitable events for ex-servicemen was its annual Poppy Day Appeal." 32 Before and after the War of Independence, civil populations actively joined remembrance ceremonies alongside veterans of the First World War. ${ }^{33}$ But while Southern authorities acknowledged the First World War, it did not feature prominently in the Free State's calendar of commemorations, whose aim was instead to enshrine its existence and legitimacy within the genealogy of Irish rebellion and revolution. From 1918 onward, commemorations of the First World War operated on a vernacular basis. ${ }^{34}$ Those who had participated in the Irish War of Independence (1919-1921) and the Irish Civil War (1922-23) enjoyed state-organized or sponsored commemorations of those events, while veterans of the First World War themselves had to play the most substantial part in

${ }^{25}$ John Coolahan, Irish Education: Its History and Structure (Dublin, 1981), 75.

${ }^{26}$ Karin Fischer, Schools and the Politics of Religion and Diversity in the Republic of Ireland (Manchester, 2016), 2.

${ }^{27}$ Fischer, Schools and the Politics of Religion and Diversity, 3.

${ }^{28}$ Fischer, 23.

29 "Remembrance Day: Impressive Scenes in Dublin," Irish Independent (Dublin), 12 November 1924.

30 "Armistice Day in Tralee," Cork Examiner, 12 November 1927.

31 "Armistice Day in Cobh," Cork Examiner, 12 November 1928.

32 Shannon Monaghan, "Whose Country, Whose Soldiers, Whose Responsibility? First World War Ex-servicemen and the Development of the Irish Free State, 1923-1939," Contemporary European History 23, no. 1 (2014): 75-94, at 83.

${ }^{33}$ Heather Jones, "Church of Ireland Great War Remembrance," 75.

${ }^{34}$ Myers, The Great War, 1. 
maintaining alive the memory of that war. Communities, villages, towns, veteran associations, and families commemorated the sacrifice of their sons.

The gap between vernacular memorials orchestrated by veterans and civilian communities and the lack of state-sponsored national commemorations has led some historians to suggest that the Southern authorities sought to erase any memory of the First World War. However, as Grayson revealed, claims that veterans were not "officially" remembered was an overstatement, as between 1924 and 1932 the Irish Free State sent representatives to Armistice Day commemorations in Dublin, ${ }^{35}$ while the Irish high commissioner participated in the ceremony at the Cenotaph in London on 11 November up until 1932. ${ }^{36}$ De Valera's government later granted a public subsidy "for the construction of the national memorial at Islandbridge." 37 Such evidence, then, requires a more nuanced approach to the Irish Free State's attitude toward commemorating the memory of Irishmen who died in the First World War.

The absence of government-sponsored national commemorations spoke not only to the radical nature of the postimperial Irish Free State but also to its identity: a state born in reaction to British imperialism. This identity was again reflected in the issue of the national memorial to the Irish Fallen. Between 1918 and 1923, the ongoing conflict forced the Irish National War Memorial Committee to suspend the task of building a suitable memorial and instead to focus on producing the War Memorial Records. ${ }^{38}$ When the civil war came to an end, the committee eventually considered ideas for the erection of a national memorial for the First World War. In 1923, as the Dáil debated the monument's location, the idea that it might be erected in Merrion Square in the center of the capital close to the parliament stirred up vehement resistance. William Cosgrave, president of the Executive Council, whose two brothers had served in the war (one was killed), recognized that "a large section of nationalist opinion regards the scheme as part of a political movement of an imperialist nature." 39 He warned the British Legion and the representatives of the Irish National War Memorial that erecting "a memorial distasteful to a large body of citizens" in the middle of the city was unthinkable. ${ }^{40}$ The vice-president of the Assembly, Kevin O'Higgins, explained: 'No one denies the sacrifice, and no one denies the patriotic motives which induced the vast majority of those men to join the British army to take part in the First World War; and yet, it is not on their sacrifice that this State is based, and I have no desire to see it suggested that it is." 41 While some individuals effectively sought to push commemorations away from Dublin's center (but refrained from overtly saying they did not want an official memorial to the First World War), the Dáil argued that the war, having not directly contributed to the state's creation, could not occupy a significant place in the political landscape of the capital.

${ }^{35}$ Grayson, Dublin's Great Wars, 327.

${ }^{36}$ David Fitzpatrick, "Commemoration in the Irish Free State: A Chronicle of Embarrassment," in History and Memory in Modern Ireland, ed. Ian McBride (Cambridge, 2001), 184-203, at 192.

${ }^{37}$ Keith Jeffery, "Echoes of War," in Horne, Our War, 261-76, at 270.

${ }^{38}$ Fitzpatrick, "Commemoration in the Irish Free State," 192.

${ }^{39}$ Letter from James McNeill (High Commissioner of the Irish Free State in London) to the President of Dáil Éireann William Cosgrave, 8 April 1926, Department of the Taoiseach, S4156A, National Archives of Ireland, Dublin.

${ }^{40}$ McNeill to Cosgrave, 8 April 1926.

${ }^{41}$ Kevin O’Higgins, Speech to Dáil Éireann, 29 March 1927, Dáil Éireann Debates (1927), vol. 29, no. 5 , cols. $400-03$. 
It would "give a wrong twist, as it were, a wrong suggestion to the origins of this State," 42 argued O'Higgins. "The State has other origins." 43 From the ashes of the War of Independence rose the Free State.

After years of hesitation and political opposition, Southern Irish authorities decided in 1929 to erect the national First World War memorial. Designed by Sir Edwin Lutyens in the 1930s, and completed by $1939,{ }^{44}$ its location at Islandbridge, opposite Phoenix Park, has generated much debate among historians. Some concluded that the state deliberately sought to put away any sign of Ireland's involvement in the conflict. ${ }^{45}$ In fact, veterans and members of the British Legion in Ireland wanted the memorial to be erected in Phoenix Park. ${ }^{46}$ General Sir William Hickie, a member of the council of the Irish National War Memorial, representative of the British Legion, and former officer-in-command of the 16th (Irish) Division, pointed out that building a national memorial in the capital's center would generate logistical issues for parades, marches, and gatherings:

Merrion Square does not lend itself to accommodate the vast concourse that we have reason to believe will assemble in days to come. Some 50,000 people came all the way to the Phoenix Park last November. When we consider that the businessmen and businesswomen of Dublin and their employees can attend without long absence from work at a place where the Irish national war memorial is to be to men from the four provinces and as the crowd would greatly exceed the numbers that have already been seen in Dublin, we must ask ourselves whether the city authorities or the Government itself would permit such a gathering in the centre of the city. ${ }^{47}$

Sir Bryan Mahon, former officer-in-command of the 10th Division, spoke in favor of Islandbridge as an ideal location to assemble for remembrance ceremonies: "Nor do I consider Merrion Square, in any way, a suitable site for a war memorial . . . Dublin is fortunately possessor of one of the finest, if not the finest, public parks in Europe. Why not take advantage of that and erect a memorial in the Phoenix Park and let it stand for ever as a memorial to 50,000 brave Irishmen who voluntarily gave their lives for their king, their country and for liberty?" 48 In the end, the choice of Islandbridge was acceptable to opponents of any sign of commemorations, the Free State government, the National War Memorial Committee, and leading veterans such as Hickie and Mahon. The choice of the site reflected the transitioning nature of the Irish state from an imperial to a national entity.

In contrast, Northern Ireland anchored its commemoration of the First World War, the Belfast Cenotaph, originally unveiled in 1929 , close to City Hall. ${ }^{49}$ The location spoke for the incorporation of the First World War within the framework and the

42 Terence White, Kevin O'Higgins (Tralee, 1966), 13.

${ }^{43}$ O’Higgins, Speech to Dáil Eireann, 29 March 1927.

${ }^{44}$ Proposal by M. J. Byrne for the erection of a memorial to the First World War, 29 October 1929, Department of the Taoiseach, S.4156A, National Library of Ireland.

${ }^{45}$ Keith, Ireland and the First World War, 67.

${ }^{46}$ Myers, Great War, 124.

${ }^{47}$ William Hickie, Speech to Seanad, 9 March 1917, Seanad Éireann Debates (1917), vol. 8, cols. 413-19.

${ }^{48}$ Bryan Mahon, Speech to Seanad, 9 March 1917, Seanad Éireann Debates (1917), vol. 8, cols. 413-19.

${ }^{49}$ Switzer, Unionists and Great War, 85. 
collective identity of Ulster Unionism. The imperial war remained central in Northern Irish history and identity as an event cementing its historical and cultural relations with Great Britain.

As First World War memorials materialized on Irish soil the memory of the conflict and became sites of remembrance illustrating popular support for the sacrifice of Irishmen, Irish war memorials were also erected in foreign lands. Erecting a memorial in France created no difficulty for either Northern Ireland and the interwar Irish Free State; both Southern and Northern authorities erected monuments in France, indicating a desire not to forget the contribution of their compatriots. On 19 November 1921, Northern Ireland prime minister Craig visited the Somme alongside Sir Henry Wilson, chief of the Imperial General Staff, General Nugent, former commanding officer of the 36th Ulster Division, the archbishop of Armagh, and several officers and men from the British army. ${ }^{50}$ They inaugurated the Ulster Tower, ${ }^{51}$ a replica of a well-known Ulster landmark, Helen's Tower. ${ }^{52}$ Southern authorities arranged for the erection of an Irish High Cross to the memory of the 16th Division in Belgium near the de Wijtschatestraat Wood on 21 August 1923; two days later, a similar cross was unveiled at Guillemont in Picardy. The president of the British Legion in Ireland, Sir William Hickie, the former commanding officer of the 16th Division, Sir Bryan Mahon, and Sir Edward Bellingham and several chaplains attended the ceremony. Members of the Dáil also participated. ${ }^{53}$ The French Ministry of War specially appointed Marshall Joffre to inaugurate the Guillemont memorial. ${ }^{54}$

Although they did not commemorate the sacrifice of Irishmen in the manner of contemporary British and Northern Irish public ceremonies, Southern authorities never forbade First World War commemorations and ceremonies and in fact provided some moral and financial support for them. Yet apart from the question of the degree of recognition that veterans met with, whether official in the North or at best unofficial in the South, was the reality of material hardship that both Northern and Southern veterans faced on their homecoming.

\section{"FORSAKEN EX-SERVICEMEN: HOUSES NOT FIT FOR PIGS" ?55}

Before the Anglo-Irish Treaty (1921), all of Ireland was an integral part of the United Kingdom. At the time when those who had served in the First World War were demobilized, the British government remained the sovereign governing authority in Ireland, even though the War of Independence had broken out in 1919. Irish

\footnotetext{
50 "Inauguration de la Tour d'Ulster," Le Progrès de la Somme (Amiens), 17 November 1921.

${ }^{51}$ Memorials and Graves: 36th (Ulster) Division at Thiepval (France), 1919-1925, TNA, WO $32 / 5868$.

${ }^{52}$ Lettre du Ministre des Régions libérées au Préfet de la Somme, 14 novembre 1921, inauguration de la Tour d'Ulster de Thiepval en l'honneur de la 36ème division, 99M47, Archives Départementales de la Somme.

${ }^{53}$ Lettre du ministre de l'Intérieur au Préfet de la Somme, 20 août 1926, inauguration du monument aux morts de Guillemont en l'honneur de la l6ème division irlandaise, 99M69/2, Archives Départementales de la Somme.

54 "Irish War Memorial Unveiled on Somme by Marshal Joffre," Lurgan Mail, 28 August 1926; "The Irish Dead: Tribute Paid on French Battlefields," Evening Herald (Dublin), 24 August 1926.

55 "Forsaken Ex-servicemen: Houses Not Fit for Pigs," Irish Times (Dublin), 4 August 1926.
} 
veterans benefited from the same official interest and rehabilitation schemes as did other veterans in England, Scotland, and Wales. In December 1919, the British government empowered the Irish Land Commission to provide holdings for former members of the crown forces who had served in the imperial war. Under the Irish Land Act (1919), the Land Commission made special provision of housing for veterans. ${ }^{56}$ Declared James MacPherson, British chief secretary, "I look forward myself to seeing large colonies of these soldiers scattered all over Ireland." 57

Without question, British economic support for Irish veterans in the thirty-two counties represented an indirect benefit for Ireland, and after partition, for both Northern and Southern authorities. The building of houses for veterans helped relieve a general housing shortage while bringing immediate employment to Irish labor and profit to Irish constructors. Ireland had experienced a severe housing crisis since early in the twentieth century. ${ }^{58}$ In 1914, "14,000 houses in Dublin were urgently needed to relieve congestion and to close tenements which were unfit for habitation." ${ }^{59}$ In April 1917, the Irish Convention's Housing Committee demanded a large postwar program to build 67,500 houses throughout Ireland. ${ }^{60}$ Thus British policy for imperial veterans "contributed to the Irish housing stock at a time when the country's housing problems and shortages were acute and economic circumstances discouraged public initiatives in housing."61 Reconstruction work financed by the British Treasury alleviated the general problem of unemployment and enabled the undertaking of necessary work that would otherwise have been a charge on public funds or been left undone for lack of money. Moreover, the decision to give priority to the veterans and to hire them to build housing projects facilitated their socioeconomic integration and contributed to the Irish economy in the long run. ${ }^{62}$

After partition and during negotiations between Southern authorities and the British government, it was clearly stipulated that arrangements had to be made between the respective governments to ensure the continuance of special assistance to veterans. ${ }^{63}$ When the British suggested that a trust could provide and maintain veterans' housing, both the Free State and the Northern Irish authorities immediately accepted. William Ormsly-Gore, undersecretary of state for the colonies, saw immediate benefits for both sections of Ireland: "I have every reason to think that, as all the money comes from this country, to discharge an obligation to ex-servicemen, neither

${ }^{56}$ Report by the Committee on Claims, 1.

${ }^{57}$ James MacPherson, Speech to the House of Commons, 18 November 1919, Parliamentary Debates, Commons, 5th series (1909-1936), vol. 121, cols. 853-64.

58 J. V. O’Brien, Dear Dirty Dublin, a City in Distress, 1899-1916 (Berkeley, 1982); J. Prunty, Dublin Slums, 1800-1925: A Study in Urban Geography (Dublin, 1998).

${ }^{59}$ Joseph Brady and Patrick Lynch, "The Irish Sailors' and Soldiers' Land Trust and Its Killester Nemesis," Irish Geography 42, no. 3 (2009): 261-92, at 264.

${ }^{60}$ Brady and Lynch, “The Irish Sailors' and Soldiers' Land Trust,” 265.

${ }^{61}$ F. H. A. Aalen, "Home for Heroes: Housing under the Irish Land (Provision for Soldiers and Sailors) Act 1919, and the Irish Sailors' and Soldiers' Land Trust," Town Planning Review 59, no. 3 (1988): $305-24$, at 306

${ }^{62}$ Report by the Committee on Claims, 35.

${ }^{63}$ Letter from British Treasury to the Provisional Government, 15 March 1922, Irish Free State Future administration of Certain Schemes which have been established for the Benefit of Ex-service members of the British Military Forces, File 4736, Ministry of Finance, T160/127, National Archives of Ireland. 
the North nor the South will reject that money." 64 The British Treasury would continue financing the scheme. During the state-building phase of Northern Ireland (1920) and the Irish Free State (1921), their respective representatives were aware that they could not financially provide for veterans. Thus both political entities welcomed the housing programs for veterans; both desperately needed houses and favored a pragmatic approach. In 1923, the Free State minister for finance, Ernest Blythe, publicly acknowledged the efficiency and importance of the British policy of house building for veterans:

We all know that within the Saorstát 30,000 or 40,000 houses are wanted. It will be a great asset to this State to have this money made available for the provision of houses, apart altogether from the carrying out of the pledges given the men who will actually be put into them . . . It would not have been easy, even if it had been possible, to have a British Government Department carrying out any function in the Saorstát. At the time it certainly was desirable that provision should be made so that the work which had been begun of providing for these men, having regard to the promises given them time and again by the British statesmen, should be continued. ${ }^{65}$

The Irish Sailors' and Soldiers' Land Trust, or ISSLT, then took over the Board of Works, an Irish agency. The trust was an imperial entity operating on an allIreland basis under the direct control of the British Treasury, entirely funded by the British government, in order to alleviate the shortage of houses in both jurisdictions. The imperial trust had no involvement whatsoever from the Free State or the Northern Irish government but was welcomed by both. As Ormsly Gore noted, "Whatever happens, we will continue to have this obligation, which was incurred in the 1919 Act, to the soldiers and sailors. We, in this Parliament, have undertaken that obligation and, whatever happens, it is up to us to see that it is properly discharged." 66 Through the ISSLT, Britain clearly asserted that it would fulfill its obligations to veterans of the First World War in Northern and Southern Ireland.

But whereas Section 1 of the Irish Land Act (1919) recognized "any men who had served in His Majesty's Naval, Military or Air Forces in the present war" as eligible and entitled to receive untenanted land and a lodging, ${ }^{67}$ the Land Act (1923) passed by the Free State abolished all existing special classes of persons for whom land might be provided. While in Northern Ireland the special provisions remained to acquire land for veterans of the First World War, in Southern Ireland British veterans were no longer specifically mentioned as a class; land could only be provided under Subsection 1 (f) of Section 31, which stated that land could go to any other person or body to whom in the opinion of the Land Commission it ought to be given. Whereas in 1919, under Section 17 of the Irish Land Act (1919) passed by British Parliament, former servicemen (including officers) in all thirty-two counties were to be given priority, from 1923 onward that privilege came to an end in the

${ }^{64}$ William Ormsly-Gore, Speech to House of Commons, 28 November 1922, Parliamentary Debates, Commons, 5th series (1909-1936), vol. 159, col. 579.

${ }^{65}$ Ernest Blythe, Speech to Seanad, 4 July 1923, Seanad Éireann Debates (1923), vol. 1, col. 1344.

${ }^{66}$ Ormsly-Gore, Speech to House of Commons, 28 November 1922, cols. 579-80.

${ }^{67}$ Report by the Committee on Claims, 3 . 
twenty-six counties of the Irish Free State. ${ }^{68}$ The British government cannot be held accountable, as the Irish Land Act (1919) was suggested, voted, and enacted by the Irish Free State to facilitate land redistribution at a time when agrarian struggle remained an embedded component of the Irish revolution. ${ }^{69}$ The ISSLT, which supervised construction of the dwellings, thus found itself in a delicate situation.

That same year, the British government fixed at 1,046 and 2,626 the total number of dwellings to be erected in Northern and Southern Ireland, respectively. ${ }^{70}$ For more than 150,000 veterans, ${ }^{71}$ the provisions were completely inadequate, stirring up disillusionment among veterans in both jurisdictions. The limit imposed on the building of houses provoked widespread suspicion among veterans that Britain was not fulfilling its moral obligations. In 1915, to motivate men to join the war effort, recruiting agents in Ireland had promised that forty thousand houses for veterans would be available after the war. Sir Henry McLaughlin recalled that Lord Kitchener, secretary of state for war, had authorized him in his capacity as general director of recruitment in Ireland to guarantee accommodation to new recruits after the war. ${ }^{72}$ The huge gap between the original forty thousand houses promised and the 3,672 lodgings to be built deepened feelings of despair among veterans. However, apart from the unofficial promises, the British had never stipulated how many houses would be built.

On the outskirts of the town of Boyle (County Roscommon, Southern Ireland), thirty-seven applicants submitted files to obtain one of eight lodgings erected in 1926. ${ }^{73}$ When the Cork County Borough Scheme was passed in 1927, the trust received eleven hundred applications for sixty cottages. ${ }^{74}$ In Larne, Northern Ireland, in 1924, the British Ministry for Finance had originally planned to build twenty cottages; in 1928, for financial reasons, the number was capped at twelve. ${ }^{75}$ In the townland of Derrylallen (Northern Ireland), only four cottages were built for the veterans. ${ }^{76}$ By November 1924, only forty-five veterans had been housed in Northern Ireland, 77 compared to 210 veterans in the Free State. ${ }^{78}$

By 1929, in Southern Ireland, the province of Leinster had a stock of 1,122 dwellings built for war veterans, followed by Munster, where 644 houses had been built; Ulster prided itself on having built 895 dwellings, while in Connaught 144 had been built. ${ }^{79}$ Ulster had raised 47 percent of all the recruits during the First World War ${ }^{80}$

${ }^{68}$ Report by the Committee on Claims, 3.

${ }^{69}$ David Fitzpatrick, Politics and Irish Life, 1913-1921: Provincial Experiences of War and Revolution (Cork, 1998), 65.

${ }^{70}$ Report by the Committee on Claims, 13.

${ }^{71}$ Report by the Committee on Claims, 3.

72 "Houses for Ex-servicemen," Irish Times (Dublin), 12 December 1927.

${ }^{73}$ Boyle no 1 RD Scheme 185 (1926-1952), Irish Sailors' and Solders' Land Trust: Southern Ireland, TNA, AP 1/107.

${ }^{74}$ Cork County Borough Scheme T12 (1926-1943), ISSLT: Southern Ireland, TNA, AP 1/19.

${ }^{75}$ Larne RD Schemes 93, 328, and 350 (1926-1954), ISSLT: Northern Ireland, TNA, AP 2/34.

76 Tanderagee RD Scheme 351 (1925-1928), ISSLT: Northern Ireland, TNA, AP 2/22.

77 Report dated 18 November 1924, Purchase of land to provide holdings for ex-Servicemen in Northern Ireland (1923-1925), TNA, HO 45/11994.

${ }^{78}$ Memorandum, 27 October 1924, Purchase of land to provide holdings for ex-Servicemen in Northern Ireland (1923-1925), TNA, HO 45/11994.

${ }^{79}$ Report by the Committee on Claims, 14.

${ }^{80}$ Memorandum, 29 November 1927, Commission to enquire into condition of British ex-servicemen in Irish Free State (1927-1929), TNA, PIN 15/757. 
and accounted for 36 percent of the overall population in Ireland; ${ }^{81}$ nearly 40 percent of all the colonies for veterans were built there. ${ }^{82}$ By March 1928, 1,927 houses had been completed in Southern Ireland and 878 in Northern Ireland. ${ }^{83}$ In April 1929, veterans occupied 297 houses in Belfast, and the ISSLT had recently authorized an additional expenditure of $£ 37,000$ for the erection of fifty-eight more cottages. ${ }^{84}$

The resentment and despair generated by the woefully insufficient housing for veterans throughout Ireland was laid at the door of British authorities. But the special provision from the Northern Irish authorities also created a widening gap between Northern and Southern veterans, illustrating the consequences of one section of the island agreeing to take some financial responsibility for them and the other section refusing to do so. Whereas the Irish Free State depended entirely upon British taxpayers for funding to build houses for the former servicemen, Northern Ireland did not. By November 1922, two years after the state's creation, Northern Irish authorities had "built between 800 and 900 houses in Belfast, and not one of those houses is occupied by other than ex-service men." 85 These dwellings were erected independently of the housing schemes supervised by the ISSLT. Overall, including the 1,046 dwellings that would be built by the ISSLT, nearly 2,000 houses in Northern Ireland would be erected for veterans only-almost as many as in the Free State. ${ }^{86}$ Local initiatives accounted for the higher number of houses for veterans in Northern Ireland, and for the small numbers of complaints relative to those from Southern Irish veterans.

Moreover, the Northern Irish state had built the only colony dedicated for disabled men, as the MP Thomas M'Connell observed: "We have also built, something which does not exist anywhere else in the whole, of these islands-a colony for absolutely disabled men. In that colony the men are living free of rent and taxes for the term of their natural life." 87 By contrast, under the ISSLT, veterans all over Ireland paid a weekly rent for every lodging. ${ }^{88}$ Thus it seemed that, thanks to the Northern Irish taxpayer, disabled veterans living in the colony in Belfast were better treated than other disabled veterans under the ISSLT. In the House of Commons, on 22 November 1922, representatives from the three nations of Great Britain praised the initiatives of the Northern Irish ruling body: "We, on this side of the House, are exceedingly pleased that the representatives of Northern Ireland have been able to secure such exceedingly good conditions for the ex-servicemen, and we should have liked to see such conditions given, where required, to any other

${ }^{81}$ Census of Ireland for the Year 1911: General Report (Dublin, 1913), 17.

${ }^{82}$ I have concluded that 40 percent of all houses for First World War veterans built in the 1920s were erected in Ulster (without, however, being able to calculate the percentage for Northern Ireland).

${ }^{83}$ Minutes of Meetings of the Irish Sailors and Soldiers Land Trust, 30 May 1927, ISSLT: Minutes (1927), TNA, AP 4/2.

${ }^{84}$ Memorandum, April 1929, Belfast County Borough Schemes 371, 372, and 375 (1927-1940), ISSLT: Northern Ireland, TNA, AP 2/38.

${ }^{85}$ Thomas E. M'Connell, Speech to House of Commons, 28 November 1922, Parliamentary Debates, Commons, 5th series (1909-1936), vol. 159, col. 588.

${ }^{86}$ M'Connell, Speech to House of Commons, 28 November 1922.

${ }^{87}$ M'Connell, Speech to House of Commons, 28 November 1922.

${ }^{88}$ Correspondence with Treasury on Adoption of Minimum Rental, letter from the ISSLT to Treasury, 6 December 1924, TNA, AP 3/3. 
body of men or women." 89 MPs openly praised the endeavor of Northern Ireland in acting independently from the ISSLT to alleviate unemployment among its veterans.

To distinguish how Irish veterans fared in comparison with the rest of the United Kingdom, more comparisons are required. ${ }^{90}$ In Scotland, by 1923, 1,304 holdings for veterans had been erected. ${ }^{91}$ The same year, in England and Wales, some 56,000 applications had been received from veterans, and 16,800 (30 percent) had received a lodging. Clearly, a higher rate of veterans registered in England obtained a dwelling than did those in Ireland. However, the legislative situation of England must be taken into account. While in England the Land Settlement (Facilities) Act (1919) meant the national government worked "through county councils to increase the number of smallholdings, "92 in Southern Ireland, the body in charge of housing veterans operated with no support from the Irish Free State, county councils, or local authorities. (To some extent, the situation was similar in Scotland). In Northern Ireland, authorities worked alongside the ISSLT and even complemented its work in financing their own lodging schemes.

Once veterans moved in, all over Ireland, the deplorable quality of some construction soon led to numerous claims against the British government. Unreliable water supply endangered the lives of children and, coupled with problematic sewerage systems, enraged the veterans. For the fifteen tenants of Brookville, the nearest available water supply was located in the town of Tipperary, more than a mile distant. ${ }^{93}$ Rain seeped in through the outside walls of all the houses. Even after four or five days of fine weather, "large damp patches were visible on the plaster of the inside walls." Rain came through the roof and into the bedrooms, forcing tenants "to resort to buckets to contain the flow." Road drainage also had serious effects on the habitability of the site. Water often came right up to the doors, washing away the thin layer of gravel on the pathways. Tenants were obliged to "wade knee deep in mud" to their houses. ${ }^{94}$ The "Bluebell" colony had thirty-two houses crowded on eight acres of land. ${ }^{95}$ At Killincarrig, ten houses were ideally located on nineteen acres of land on the outskirts of Bray, with each tenant entitled to half an acre of garden. However, the bad quality of the building work brought protests. The colony had to endure the stench of "open sump pits," infuriating tenants who also had to put up with the driving rain that came in "through the walls and windows," and "the gusting of the gales under the doors." 96

While the grievances were completely legitimate, they were wrongly directed against British authorities. After the establishment of the Irish Free State, the ISSLT had inherited 1,508 properties from the Board of Works, the Irish authority

\footnotetext{
${ }^{89}$ Valentine McEntee, Speech to House of Commons, 28 November 1922, Parliamentary Debates, Commons, 5th series (1909-1936), vol. 159, col. 591.

${ }^{90}$ On houses for veterans in Great Britain, see the recent publication by Trevor Yorke, Homes Fit for Heroes: The Aftermath of the First World War, 1918-1939 (London, 2018).

${ }^{91}$ Aalen, "Home for Heroes," 307.

92 Aalen, 306.

93 Tipperary RD, Scheme 24 (1924-1953), ISSLT: Southern Ireland, TNA, AP 1/24.

94 Tipperary RD, Scheme 24 (1924-1953), ISSLT: Southern Ireland, TNA, AP 1/24.

95 South Dublin RD Scheme 120 (Bluebell) (1924-1956), ISSLT: Southern Ireland, TNA, AP 1/29.

${ }^{6}$ Report from Sergeant Duckworth, 6 August 1926, Rathdown no 1-2 RD Schemes 26 and 151 (1925-1948), ISSLT: Southern Ireland, TNA, AP 1/58.
} 
responsible for the construction of the houses. ${ }^{97}$ The Board of Works had made some disastrous mistakes in the construction of these housing schemes; its inability to inspect and check the quality and reliability of the builders and hold them accountable was a major one. The ISSLT had to cover all the costs of repairs.

Northern Irish veterans experienced similar complications. In Ballymena, no provision had been made for a water supply and tenants had to fetch their water from a well 540 yards away. ${ }^{98}$ Numerous complaints were received from the tenants of Cookstown; windows let in rain, mainly through the top portion of the sash. ${ }^{99}$ In Hillsborough, defective bricks in the chimneys resulted in dampness leading to the rapid deterioration of the walls. In eight out of the nine cottages, chimneys had to be taken down and rebuilt. ${ }^{100}$ In Lisburn, improvements to drainage had to be carried out to alleviate flooding. ${ }^{101}$ In 1926, the Northern Irish daily Northern Whig published a diatribe from the chairman of the Ministry of Finance overtly targeting the British authorities: "It was a perfect scandal the way in which the ex-servicemen of Lurgan were treated by the Imperial Government.” Originally, eighteen houses were to be built in Lurgan, but the number was decreased to twelve, generating much resentment among veterans. ${ }^{102}$

News of the deplorable living conditions in the colonies for veterans spread across the island, to the point where in 1927 the Irish Times in Dublin published an article titled "Tenements for Heroes"103 to illustrate the conditions in which veterans were left to live in both Northern and Southern Ireland. However, as scandalous as conditions were, they were already common. The sump-pit system had "generally been a failure throughout the country; a cause [was that it was] not fool-proof and the drains easily blocked by old rags, stones of all kinds and abnormal matter."104 Overcrowding and poor sanitation were also widespread. In 1911, out of 861,879 dwellings registered for the whole island, more than 58,000 (6.4 percent) had only one room. ${ }^{105}$ In 20 percent of cases in the category, more than five household members shared the single room, and as many as twelve people could be living there in conditions of severe overcrowding. ${ }^{106}$ The Irish Times wanted to blame British authorities but failed to note that the Board of Works responsible for building the houses operated as an Irish agency totally independent from the British government. ${ }^{107}$ Such unfounded accusations spoke to the charged political climate where all claims and concerns could be regarded through the lenses of ambiguous and conflicting Anglo-Irish relations.

Demand greatly exceeded supply in both North and South. Nevertheless, to blame the British government for the deplorable quality of the houses built would be

\footnotetext{
${ }^{97}$ Brady and Lynch, “The Irish Sailors' and Soldiers' Land Trust,” 270.

98 Ballymena RD Scheme 59 (1924-1962), ISSLT: Northern Ireland, TNA, AP 2/9.

${ }^{99}$ Cookstown RD Scheme 282 (1923-1962), ISSLT: Northern Ireland, TNA, AP 2/10.

${ }^{100}$ Hillsborough RD Scheme 47 (1924-1958), ISSLT: Northern Ireland, TNA, AP 2/23.

${ }^{101}$ Lisburn RD scheme 329 (1928-1954), ISSLT: Northern Ireland, TNA, AP 2/40.

102 "Housing the Ex-Service Man," Northern Whig and Belfast Post, 5 August 1926.

103 "Tenements for Heroes," Irish Times (Dublin), 23 December 1927.

${ }^{104}$ Letter from the Dublin Trust to Duckworth, 1 September 1926, Rathdown no 1-2 RD Schemes 26 and 151 (1925-1948), ISSLT: Southern Ireland, TNA, AP 1/58.

${ }^{105}$ Census of Ireland for the Year 1911, 17.

106 Census of Ireland for the Year 1911, 4.

107 "Tenements for Heroes," Irish Times (Dublin), 23 December 1927.
} 
erroneous. The ISSLT had inherited the properties and covered the costs of bringing them up to standard. The capping of the number of houses to be built indeed generated resentment, but both Northern and Southern Ireland were affected by limited stock. It is, however, true that the Northern Irish Parliament in Stormont passed a number of resolutions permitting the financing of hundreds of dwellings for veterans of the First World War; the Dáil Éireann did not. ${ }^{108}$

\section{PARTITION, IMPERIAL OBLIGATIONS, AND STATE BUILDING}

Throughout the United Kingdom, unemployment severely affected the lives of those who had served in First World War. One factor in the high unemployment rate was the Irish government's wartime prohibition of emigration. When, "under normal conditions," thirty thousand people on average had emigrated from Ireland every year, the unemployed population "might have been absorbed by emigration."109 By 1919, "emigration from Ireland had declined by $90 \%$ as compared with 1913 and the actual number of emigrants leaving Ireland in 1919 was something less than $4,300 . " 110$

At the start of 1920, British authorities recorded 27,648 unemployed veterans in Ireland-33 percent of the 83,500 demobilized men and officers there. ${ }^{111}$ (By comparison, in Great Britain at that time, out of 3,365,000 demobilized veterans, 311,646 men and officers were unemployed-approximately 9 percent of the total. ${ }^{112}$ ) Irish veterans relied on unemployment gratuities directly paid by the British government. Between 11 November 1918 and 6 February 1920, the employment exchanges of the Ministry of Labour placed 8,610 veterans in employment in Ireland; ${ }^{113}$ in March 1920, 22,884 veterans still remained on the registers of employment exchanges. ${ }^{114}$ Even though, as Paul Taylor has shown, British government departments made significant efforts to help veterans in Ireland ${ }^{115}-33$ percent of civil servants working for the Ministry of Pensions in Ireland in August 1920 had returned from the trenches, ${ }^{116}$ as had 80 percent of the staff employed by the

${ }^{108}$ M'Connell, Speech to House of Commons, 28 November 1922.

${ }^{109}$ Correspondence with the Irish Department regarding the position of ex-service men in Ireland, memorandum, 30 March 1920, Employment Department and Employment and Insurance Department, TNA, LAB 2/747/ED106/16/1920.

${ }^{110}$ Correspondence concerning the position of ex-service men in Ireland, memorandum prepared by T. W. Philips, Employment Department and Employment and Insurance Department, TNA, LAB 2/ 855/ED5412/7/1921.

${ }^{111}$ Correspondence regarding the situation of ex-service men and officers in Ireland, Memorandum, 23 February 1920, TNA, LAB 2/855.

112 Correspondence regarding the situation of ex-service men and officers in Ireland, Memorandum, 23 February 1920, TNA, LAB 2/855.

113 Robert Horne, Speech to the House of Commons, 19 February 1920, Parliamentary Debates, Commons, 5th series (1909-1936), vol. 125, cols. 1029-32.

${ }^{114}$ Correspondence regarding employment of ex-service men and officers in Ireland, Memorandum, 30 March 1920, Ministry of Labour, TNA, LAB 2/747.

115 Taylor, Heroes or Traitors, 91-136.

116 Correspondence concerning the position of ex-service men in Ireland, memorandum, 23 February 1920, Employment Department and Employment and Insurance Department, TNA, LAB 2/855/ ED5412/7/1921. 
Ministry of Pensions in the Dublin district at that period ${ }^{117}$ - the numbers were insignificant, representing only 350 veterans. ${ }^{118}$

In Belfast and Tipperary, Government Instructional Factories undertook disability training. By January 1921, the instructional factory in Belfast had trained 102 men. One year later, in January 1922, it registered 1,101 men trained, 824 in training, and 2,669 on the waiting list. At that time, the instructional factory in Tipperary listed 1,772 men who had completed their training, 795 were in training, and 2,699 were awaiting a place. ${ }^{119}$ In May 1923, taking into account all the various training schemes, Northern Ireland registered 2,330 men who had completed their training, while 1,057 were still finishing. In Southern Ireland, British authorities estimated that 2,966 veterans had completed the scheme and 617 were still in training. ${ }^{120}$

In September 1919, King George V had launched a network throughout the United Kingdom intended to support the economic rehabilitation of veterans. The King's National Roll asked that British employers, industries, and companies hire a minimum of 5 percent of disabled war veterans. ${ }^{121}$ In 1921, more than one hundred firms in Northern Ireland had signed up to the scheme. By 1924, the number had increased fivefold, with 505 companies having hired disabled veterans. ${ }^{122}$ In Southern Ireland, however, no steps were taken to apply to the King's National Roll, as the country had no local employment committees. ${ }^{123}$ That situation accounted for the claim that British veterans in the Irish Free State were at a decided disadvantage to their comrades in Ulster and across the water. ${ }^{124}$ However, as Taylor noted, "employers who desired to co-operate in the scheme were entitled to do so." 125 Some of the largest employers in the Free State, such as the Guinness Brewery and Jacob's Biscuit Factory, adopted the principle of the King's Roll and gave preferential treatment to British veterans. ${ }^{126}$ Local war pension committees also registered for the scheme. ${ }^{127}$

In addition, local authorities and county councils in Southern Ireland contributed, with limited effect, to the employment of veterans. Between 1921 and 1922, the urban district of Fermoy (County Cork) hired 154 veterans to build and repair

\footnotetext{
117 George Tryon, Speech to the House of Commons, 16 August 1920, Parliamentary Debates, Commons, 5th series (1909-1936), vol. 133, cols. 585-86.

118 Taylor, Heroes or Traitors, 102.

119 Resume of the work of the training department of the ministry of Labour in Ireland (1922), Department of the Taoiseach, TAOIS/S 983, National Archives of Ireland.

${ }^{120}$ Administration of Training Schemes in Northern and Southern Ireland, Memorandum 6 July 1923, TNA, LAB $2 / 528$.

${ }^{121}$ Taylor, Heroes or Traitors, 92.

${ }^{122}$ Letter from the Minister for Labour to Colonel Spender, 6 February 1924, Cabinet Secretariat, $\mathrm{CAB} 9 / \mathrm{C} / 8 / 1$, Public Record Office of Northern Ireland, Belfast (Hereafter citations to this repository are abbreviated PRONI.)

${ }^{123}$ Letter from the Ministry of Labour to the Comrades of the Great War, 11 May 1920, TNA, LAB 2/220.

${ }^{124}$ Michael Heffernan, Speech to Dáil Éireann, 16 November 1927, Dáil Éireann Debates (1927), vol. 21, col. 1430 .

125 Taylor, Heroes or Traitors, 106.

${ }^{126}$ Commission to enquire into condition of British ex-servicemen in Irish Free State (1929-1930), TNA, PIN 15/758.

${ }^{127}$ Letter from the Ministry of Labour to the Comrades of the Great War, 8 July 1920, TNA, LAB 2/220.
} 
roads. The urban district of Lurgan (County Armagh) employed sixteen veterans, the Down county council (Northern Ireland) employed eleven, the urban district of Dun Laoghaire employed twenty-five, and Galway county council employed three. Twenty veterans found employment with the county council of Kilkenny, fortyone with the county council of Offaly, and seventy found work in the urban district of Longford. ${ }^{128}$

By the end of 1919, local authorities and county councils had enabled 3,400 veterans to find employment in public works throughout Ireland. By February 1920, 8,610 veterans in Ireland had been placed in employment. ${ }^{129}$ However, in 1920, in Belfast alone, 3,500 veterans and officers were still looking for work. ${ }^{130}$ At that time, the Belfast Local Committee reported that six hundred men were awaiting training, and while no doubt a number of them would be placed in training with various employers and in the recently opened Instructional Workshops, the committee secretary noted, "A great many of them-I fear the majority of them-will not be placed for months to come." "131 After partition, Northern Ireland had decided not to be entirely dependent upon funding from the British government to relieve unemployment. Between 1920 and 1922, £1,000,000 had been spent from Northern Irish revenues in Belfast for the purpose of relieving unemployment among war veterans, and an additional $£ 1,000,000$ had been granted for the same purpose. ${ }^{132}$ In 1924, Belfast's mayor invited the assistance of a delegation of more than one thousand business owners to employ the 6,363 disabled veterans living in the city. ${ }^{133}$ Thus local and state authorities clearly became involved in the socioeconomic reintegration of veterans, something that did not happen in Southern Ireland.

Instead, in 1923, the Free State's Executive Council's president, William Cosgrave, called on private employers to rehire former members of the National Forces: "Manifestly, it is the first duty of employers to reinstate men who left their employment to join the National Forces in the hour of the country's need; and secondly, to set aside a fair proportion of vacancies for those who have rendered such loyal service to the people's cause."134 In other words, the Southern authorities requested private employers to help reintegrate former members of only the IRA and the National Army, incorporating these groups of "loyal" veterans in the local framework-but no calls were launched to relieve unemployment among "British" veterans.

However, private employers and owners of companies and shops in Southern Ireland could, if they wanted, hire them. Mathew Delaney found employment in

${ }^{128}$ Work of reconstruction for ex-service men and officers (1921-22), FIN 1/21, National Archives of Ireland

129 Robert Horne, Speech to House of Commons, 19 February 1920, Parliamentary Debates, Commons, 5th series (1909-1936), vol. 125, cols. 1029-32.

${ }^{130}$ Letter from the ministry of Labour in Belfast to Colonel Spender, Secretary for the Northern Ireland Government, 6 February 1924, Cabinet Secretariat, CAB9/C8/1, PRONI.

${ }^{131}$ Letter from Belfast Local Committee to Under Secretary for Ireland, 18 March 1921, training of disabled ex-service men. Resolution by Belfast War Pension Committee, Assistant Under Secretary's Office, AUS 1/47, PRONI.

${ }^{132}$ M'Connell, Speech to House of Commons, 28 November 1922.

${ }^{133}$ Letter from the ministry of Labour in Belfast to Colonel Spender, Secretary for the Northern Ireland Government, 6 February 1924, Cabinet Secretariat, CAB/9/C8/1, PRONI.

${ }^{134}$ Letter from President Cosgrave to employers, 12 October 1923, Resettlement in Civil Employment, Department of the Taoiseach, 3/S1956, National Archives of Ireland. 
the accounting department of Messrs. Henry Ford \& Son after serving two years in the Royal Air Force. ${ }^{135}$ Former members of the crown forces received support from William Robinson, who carried on a business as wholesale and retail merchant under the name of James Pim \& Son: "Over 25 per cent of my hands," Robinson stated, "were British ex-service men." ${ }^{36}$ A well-known loyalist in Mountmellick (County Laois), Robinson's action was consistent with his Unionist convictions. Indeed, some employers who had enrolled in the British army during the war and returned to Ireland offered preferential treatment to their comrades-in-arms; comradeship among veterans played an important role in helping demobilized veterans find jobs. ${ }^{137}$ Thus some private employers found themselves in a position of partially compensating for the covertly discriminatory policies against British veterans in some parts of the country. Although their contribution cannot be precisely measured, they undoubtedly helped to attenuate unemployment among veterans, facilitating their transition into civilian life.

Yet in the climate resulting from the War of Independence and the Irish Civil War, businesses in some places refused to hire veterans identified as being former British army. This was mainly the case in places where employment was scarce and where a majority of the population nursed resentment toward Britain after the atrocities committed locally by the Black and Tans during the struggle for independence. When Thomas McCarty obtained his demobilization in January 1919 after having served two years and a half in the British Expeditionary Corps in Egypt, he presented himself to his former employer in Ennistymon (County Clare) and was abruptly "told to go and work for the people [he] fought for." Searching for employment elsewhere, he faced "a blank refusal in each instance." 38 Thomas O'Brien, his three brothers, and their father "had served in the British Forces and no one wanted to have anything to do with the family."139 After returning to Clare in November 1919, O'Brien was unable to secure employment for twelve months. John Wallace regretted that on his return from the war, "there was not much room for an ex-service man in Cork City." 140

Opposition to hiring the veterans was embedded in economic conditions. As David Fitzpatrick pointed out, by 1919, "the arrival home of hordes of former soldiers seeking jobs" ${ }^{\prime 41}$ seriously threatened agricultural and working-class communities in the competition for work. In the light of endemic plight of poverty and underemployment in Ireland, any policy of preference directed toward veterans fueled bitter hostility. Unemployment and underemployment in the post-independence period made it difficult for anyone to find a job, as evidenced by the following witness statements: "In Thurles. . . employment is scarce. Ex-servicemen are not young and sometimes disabled. There are many young men in competition against them and in the groups which congregate at corners ex-servicemen are not in the majority by any means. Templemore has no employment to offer a population

\footnotetext{
${ }^{135}$ Witness statement from Mathew DeLaney, 3 March 1928, TNA, CO 762/160/7.

${ }^{136}$ Witness statement from William Robinson, 7 January 1927, TNA, CO 762/101/19.

137 War diary of Lieutenant Stewart-Moore (1914-1918), 77/39/1, p. 57, Imperial War Museum.

${ }^{138}$ Witness statement from Thomas McCarthy, 8 February 1927, TNA, CO 762/122/11.

${ }^{139}$ Witness statement from Thomas O’Brien, 8 February 1927, TNA, CO 762/108/5.

${ }^{140}$ Witness statement from John Wallace, 17 April 1928, TNA, CO 762/175/9.

${ }^{141}$ Fitzpatrick, Politics and Irish Life, 233.
} 
prominently made up of ex-servicemen, as is the case in most Southern towns."142 In western counties such as Galway, Clare, and Mayo "the ex-service population is quite small," yet unemployment was still "most rife." 143

Free State authorities cannot be held accountable for the refusal of some private entrepreneurs to hire veterans of the First World War, a matter of personal initiative. Southern Irish veterans had good reason to be worried when faced with economic ostracism, but what increased their concerns was the lack of any preferential treatment by the state. The British government unquestionably undertook to stand back from its imperial obligations during Anglo-Irish Treaty negotiations with representatives of the Irish Provisional Government in 1921. Britain had tried to transfer some of the financial burden of supporting economic rehabilitation of veterans to the newly created Irish Free State, asking it to cover 50 percent of the costs. After several weeks of intense disagreement, the Free State insisted that rehabilitation of veterans was "clearly an imperial debt" 144 and categorically refused to contribute. It agreed that veterans were entitled to the fulfilment of promises made to secure their enlistment; Dublin was prepared to cooperate fully with the British government and to place at its disposal a reasonable extent of the powers necessary in order to fulfil these obligations. However, Free State authorities underlined that what was owed these Irishmen was "a British Imperial obligation and [it could not] be contended that it owed its existence to any action or promise of a representative Irish authority."145 This staunch position resulted from pragmatic considerations. First, Dublin could not consent to having to raise funds from the Irish taxpayers for a purpose that would have been contrary to its perception of the public interest. In addition, the liability of the British government had plainly been defined in Article 5 of the Treaty of the 6th December, although the article did not mention any sum relative to what was unquestionably the imperial moral responsibility.

The Irish authorities' refusal to contribute 50 percent of the cost of the reintegration of First World War men and officers, coupled with the British authorities at least partially reneging on imperial obligations, outraged veterans. Their fury was exacerbated when they learned that Southern authorities were supporting the reintegration of men and officers who had actively fought against the British presence in Ireland during the War of Independence, and that the Dáil was passing a number of circulars to support former IRA members. From the signing of the Anglo-Irish Treaty onward, it was the veterans who had participated in the Irish War of Independence who received preferential treatment in employment schemes. ${ }^{146}$ Department of Finance circular no. 29/23 (dated 26 July 1923) and circular no. 42/23 (dated 15 October 1923) illustrated the decision in relation to the steps to be taken to provide civil employment in government departments for officers and men

\footnotetext{
${ }^{142}$ Commission to enquire into condition of British ex-servicemen in Irish Free State, Alleged discrimination against ex-servicemen in Ireland, minute sheet, 18 June 1936, TNA, PIN 15/738.

${ }^{143}$ Commission to enquire into condition of British ex-servicemen in Irish Free State, Alleged discrimination against ex-servicemen in Ireland, minute sheet, 22 June 1936, TNA, PIN 15/738.

${ }^{144}$ Letter from British Treasury to the Provisional Government, 15 March 1922, Irish Free State, Future administration of Certain Schemes which have been established for the Benefit of Ex-service members of the British Military Forces, TNA, T160/127, fol. 4736.

${ }^{145}$ Letter from Ministry for Finance, Provisional Government to the British Treasury, 29 March 1922, TNA, T160/127.

${ }^{146}$ Report by the Committee on Claims, 36.
} 
demobilized from the National Army. Implementation of circular no. 42/24 (dated 12 November 1924), dealing with the order of discharge of temporary staff, the recruitment of permanent clerks by examination, and the cessation of temporary work, required the discharge of staff employed on a temporary basis. The Free State fixed an order of priority to be observed in laying off such staff. ${ }^{147}$ Again, former members of the National Forces clearly received preferential treatment. Veterans of the First World War felt they were treated as a "subsequent category to ex-national army members." 148 Taken together, the circulars reflected the Free State's conviction as to its moral obligation toward officers and men who had participated in its establishment. However, it must be underlined that among the 58,300 men who fought in the National Army, ${ }^{149}$ nearly 50 percent were veterans of the First World War. ${ }^{150}$ These veterans benefited from preferential treatment only insofar as they had participated in the War of Independence alongside the IRA.

Then another decision deepened their despair. In 1926, the Free State decided to demobilize veterans of the First World War serving in the Defense Forces instead of demobilizing former IRA members. ${ }^{151}$ The decision created further uproar among the veterans. Was it a deliberate discriminatory act?

Veterans of the First World War serving in the Irish Free State army were still receiving monthly British war pensions. Talks between the Irish Free State and British authorities underlined the consistent and pragmatic approach of both governments. Both agreed that a citizen of the Irish Free State should not receive a British war pension while serving in the National Army. Veterans of the First World War who were currently members of the Irish Free State army were demobilized and allowed to keep their British war pensions. Irish authorities demobilized these veterans in order to allow unemployed former members of the IRA to join the department. Yet the Irish Free State's intent was not to discriminate against veterans of the First World War. In terms of purely budgetary logic, it was undesirable to retain men who were receiving both a British pension and a monthly payment from the Irish Free State. ${ }^{152}$

The British Legion in Ireland echoed the concerns of its members and requested that the Free State enact "a preferential policy for WWI veterans"153 as was the case in Northern Ireland. There veterans were given preferential treatment for some civil service jobs; private companies such as Sirocco, ${ }^{154}$ Harland \& Wolff, ${ }^{155}$

\footnotetext{
${ }^{147}$ Report by the Committee on Claims, 49.

${ }^{148}$ William Archer Redmond, Speech to Dáil Éireann, 16 November 1927, Dáil Éireann Debates (1927), vol. 21, col. 1402.

149 Joseph Lee, Ireland, 1912-1985: Politics and Society (Cambridge, 1989), 96.

${ }^{150}$ Bryan Cooper, Speech to Dáil Éireann, 16 November 1927, Dáil Éireann Debates (1927), vol. 21, col. 1403 .

${ }^{151}$ Report of the meeting of 25 June 1926, British Army Pensioners serving in Army, Department of Defence Files, IE/MA/DOD/A13672, Military Archives of Ireland, Dublin.

${ }^{152}$ Report of the meeting of 25 June 1926, British Army Pensioners serving in Army, Department of Defence Files, IE/MA/DOD/A13672, Military Archives of Ireland.

${ }^{153}$ Report by the Committee on Claims, 49.

${ }^{154}$ Correspondence related to Sirocco Engineering Works, Papers of the Davidson Family (18701972), D3642, PRONI.

155 Correspondence related to employment for WWI veterans, Harland \& Wolff Papers (1861-1987), D2805, PRONI.
} 
James Mackie \& Sons, ${ }^{156}$ and Belfast Ropeworks ${ }^{157}$ also pledged support. Children of deceased soldiers received clothing from firms and local authorities, ${ }^{158}$ something that did not happen in Southern Ireland. In 1926, under the Local Government (War Service Payments) Act, the Northern Irish government demanded that local authorities take into account for all veterans the increase in salary that would have occurred had they not enrolled in the British army. Gas and electricity companies, tramway companies, and city halls received claims for veterans. For the year 1926 alone, the law permitted $£ 18,000$ to be dispatched to that end. It also stipulated that the widow of a deceased veteran was entitled to restitution of his income for a period of twenty-six weeks. ${ }^{159}$

Endemic consequences of the Anglo-Irish Treaty did not allow for preferential treatment of veterans of the First World War in Southern Ireland. In addition, the decision made by the British government caused resentment among veterans, leading the Committee on Claims of British Ex-servicemen to point out that they undoubtedly suffered from the directives, as compared to their Northern Irish comrades. Moreover, under the Empire Settlement Act passed on 31 May 1922 (between the date of signature of the treaty and the date of its ratification), the British government took on certain financial provisions in order to assist veterans in the United Kingdom wishing to emigrate to other parts of the empire such as Canada and Australia. British veterans resident in the Free State were not eligible for the benefits of the act. As to whether or not this was an omission or a deliberate exclusion, the Committee of Claims concluded that the British government knew that veterans in Southern Ireland would later be excluded from the provisions. ${ }^{160}$ One is inclined to argue, as the committee seems to suggest, that the British government ensured that veterans of the First World War in the twenty-six counties were not granted the same privileges as were those in the United Kingdom: "The Act should have been framed so as to define the position of these men in the Free State. Further, that such men should not be placed in less fortunate position than men resident in Great Britain, and that they should be permitted to benefit by the financial provisions of the Act." 161 In other words, special dispositions for the emigration of Southern Irish veterans should have been incorporated to grant them the same rights as Northern Irish veterans.

But from a legal aspect, Southern Irish veterans came directly under the authority of the Free State. Questions related to their emigration were purely a domestic affair. Beyond the continuation of schemes and the building of colonies, the British government did not want to encroach on the sovereignty of the Dáil. Significantly, before the signing of the Anglo-Irish Treaty (1921), the Provisional Government had opposed the emigration of veterans of the First World War. That is evident from

${ }^{156}$ Business records of James Mackie \& Sons Ltd., Heavy Machinery Manufacturers, Belfast (18601991), D3964, PRONI.

157 Papers of Belfast Ropeworks Company Ltd (1834-1983), D2889, PRONI.

${ }^{158}$ List of names and addresses of ex-servicemen whose children are recommended for clothing, 24 February 1922, Papers of the Irish Unionist Alliance (1880-1963), D989/B/2/1/1-4, PRONI.

${ }^{159}$ Meeting of the Ministry of Finance, 23 September 1926, File relating to claims by ex-servicemen for War Bonus (1914-1932), Ministry of Labour, LA/7/29BA/20, PRONI.

${ }^{160}$ Report by the Committee on Claims, 34.

${ }^{161}$ Report by the Committee on Claims, 35. 
the fact that before the passing of the Empire Settlement Act (1922), the newly elected MPs had voiced their indignation at the imperial British policy allowing veterans to emigrate to British dominions. On 5 June 1920, Cathal Brugha, minister for defense, had published a manifesto in which he accused British authorities of bleeding the country of its youth. ${ }^{162}$ Dáil Éireann believed the immigration schemes were a strategy undertaken by the British to weaken Ireland: "The enemy has declared that there are too many young men in Ireland, and he is anxious to clear them out." 163

Northern Irish authorities too resented the possibility of veterans emigrating. As Kent Fedorowich has pointed out, "Sir James Craig and his Unionist supporters could ill afford to lose too many of their Protestant brethren to emigration agents." 164 Even though less than 10 percent of veterans had left Ireland in 1919, both Northern and Southern Irish authorities were apprehensive that the emigration of young Irishmen would weaken Nationalist and Unionist movements in the island. ${ }^{165}$ However, the British approach during the passing of the Empire Settlement Act worsened the situation of Southern veterans-pointing to the need to nuance Taylor's claim that "complaints regarding the exclusion of Southern Irish ex-servicemen from the Empire Settlement Act 1922 seem unjustified." 66 Newspapers noted that emigration would have helped Southern Irish veterans "to escape from misery and unemployment,"l67 a belief shared by the Committee of Claims. ${ }^{168}$ Both Northern and Southern Ireland had objected to the emigration of war veterans during the revolution (1918-24), but in the end, while Northern Irish veterans were eligible under the act, Southern Irish veterans could not benefit from it and so had no legal means to emigrate.

Unemployment among Southern Irish veterans increased significantly when, following the Anglo-Irish Treaty, British troops left the twenty-six counties. Large sectors of the local population who had relied on the British army for employment as auxiliary or maintenance staff or for business contracts in supplying provisions now found themselves losing employment or contracts. ${ }^{169}$ This was a cause of widespread concern. ${ }^{170}$ When the British garrison was evacuated from Birr in 1922, the nearby village of Crinkle, where a large number of veterans lived, had directly experienced "greatly altered local conditions." "In May 1927, former padre (chaplain)

\footnotetext{
${ }^{162}$ Manifesto of the Ministry of Defence, Cathal Brugha, 5 June 1920, MS 8415, National Library of Ireland.

${ }^{163}$ Letter from William Murphy to Michael Collins, 25 May 1920, DE 2/37, National Library of Ireland.

${ }^{164}$ Kent Fedorowich, "Reconstruction and Resettlement: The Politicization of Irish Migration to Australia and Canada, 1919-29," English Historical Review 114, no. 459 (1999): 1143-78, at 1178.

165 Correspondence regarding the situation of ex-service men and officers in Ireland, 23 February 1920, TNA, LAB 2/855.

166 Paul Taylor, Heroes or Traitors, 133.

167 "Emigration of Ex-Servicemen," Irish Times (Dublin), 24 November 1927.

${ }^{168}$ Report by the Committee on Claims, 35.

${ }^{169}$ Letter from J. S. McElveen (Superintendent of the Curragh) to Michael Collins, 19 January 1922, Mulcahy Papers, P7/B/102, University College Dublin Archives.

${ }^{170}$ Evacuation of British Posts, memorandum on the Conditions of Unemployment that has arisen in the Curragh Area consequent to the Withdrawal of the Troops from the Curragh, Droichead Nus, and Kildare, 2 February 1922, Mulcahy Papers, P7/B/102, University College Dublin Archives.

${ }^{171}$ Birr nol RD Scheme 262 (1924-1948), ISSLT: Southern Ireland, TNA, AP 1/45.
} 
Gilmour Neill, president of the Ballyshannon Branch of the British Legion, denounced the "deplorable conditions under which may of these men are compelled to live." He went on, "The men who gave their all to the Empire in its hour of need are dragging out a wretched and hopeless existence in unsanitary uncomfortable and highly rented hovels. We are a very obscure and poverty-stricken community unable to bring any pressure to bear upon the powers that could help us and in the past all our pleading has been in vain." 172

In the years after partition, the fate of Southern Irish veterans aroused concerns in England, leading to the inauguration in 1922 of the Southern Irish Loyalists Relief Association in Westminster. ${ }^{173}$ As its name indicates, it focused entirely on raising awareness of the fate of loyal subjects in Southern Ireland. The association wanted to assist deserving veterans and their families by sending them help in the form of food tickets and clothes, and by obtaining employment for them whenever possible. ${ }^{174}$ Two-page leaflets carried statements from five Southern Irish veterans narrating their personal tragedies. The leaflet revealed the drastic impact on the socioeconomic fabric in numerous localities throughout Ireland of the withdrawal of British troops following the Anglo-Irish Treaty, and the direct consequences of living in a state that did not undertake to support imperial veterans, as was the case in Northern Ireland.

\section{CONCLUSION}

A comparative approach to the respective demobilizations of veterans of the First World War in Northern and Southern Ireland reveals that the political responses to their homecoming were closely tied to state building and national identities. In Northern Ireland, to be a veteran guaranteed special treatment from the government, while in Southern Ireland, First Word War veterans were overshadowed by parallel and competing groups of veterans involved in the creation of the Free State. In Southern Ireland, the gap between national and local commemorations reflected the revolutionary nature of the postimperial state, while in Northern Ireland, the First World War merged with the Unionist commemorative canon and cultural ethos of the new political entity and helped cement and strengthen cultural and historical relations with Great Britain.

To argue that the British government did not fulfill its moral responsibilities and ignored British veterans in both Northern and Southern Ireland would be historically inaccurate. In both states, veterans faced similar challenges. However, while some of the difficulties faced by the veterans in Southern Ireland emerged from the creation of the Free State, they also sprang from the initiatives of the British and the indifference of the Southern Irish authorities. The failure to establish adequate substantive provisions during treaty negotiations was a matter of deep resentment for Southern Irish veterans. Thus, while endorsing Paul Taylor's statement that Southern Irish

\footnotetext{
${ }^{172}$ Letter from Neill Gilmour to Field Marshall Lord Methuen, 10 May 1927, Ballyshannon UD Scheme T 42 (1925-1950), ISSLT: Southern Ireland, TNA, AP 1/126.

${ }^{173}$ Minutes of meeting held on May 1922 regarding the creation of the Southern Irish Loyalist Association, 30 May 1922, Southern Irish Loyalist Association Papers (1922-1963), D989/B/1/1, PRONI.

174 "Irish Ex-servicemen: Fate of Loyalists Who Fought for the Empire," 1925, Printed Pamphlets and Handbills (1883-1945), D989/C/1/68, PRONI.
} 
veterans were "equal citizens of the state," 175 and backing the conclusions of the Committee of Claims of British Ex-servicemen that most of the difficulties faced by Southern Irish veterans "were the result of the setting up of the Free State as a distinct entity," 176 this comparative approach reveals that imperial veterans were not well looked after by the Southern authorities and could not emigrate or purchase land in the British dominions, as was the case for their Northern Irish comrades.

The history of demobilized war veterans in Ireland reveals significant differences between a political entity viewing the Great War as intrinsically linked to its history and a newly created state emerging from the ruins of its war against a former imperial power. Attention to the experiences of both Northern and Southern Irish veterans suggests the need to rethink narratives of discrimination to acknowledge more fully the ongoing difficulties veterans faced in both parts of Ireland. Grievances existed, too, among veterans in Europe; almost everywhere in France, as historian Bruno Cabanes noted, "as far as ex-service men and officers were concerned, the moment of reintegration was almost necessarily a moment of frustration." 177 Northern Irish veterans suffered from the shortage of houses, badly built dwellings, and the plague of unemployment; however, they knew they would receive assistance from both the imperial government in Westminster and their own government in Stormont. For Southern Irish veterans, their resentment found legitimacy before and in the aftermath of the signing of the Anglo-Irish Treaty. Their challenges personified the transitioning nature of the state. While Northern Irish veterans shared a common sense of belonging with the rest of the population, Southern veterans came to see themselves as British vestiges in a postwar state and in time viewed themselves as neither the children of Great Britain nor the children of the Irish Free State.

175 Paul Taylor, Heroes or Traitors, 171.

176 Report by the Committee on Claims, 2.

177 Bruno Cabanes, La Victoire endewillée: La sortie de guerre des soldats français (1918-1920) (Paris, 2004), 279. 